\title{
Higher polythionic acids - the precursors for formation of thallium sulphide layers on polyethylene surface
}

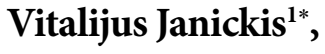 \\ Ingrida Bružaite் $\dot{2}^{*}$ \\ ${ }^{1}$ Kaunas University of Technology, \\ Radvilènu Rd. 19, \\ 50254 Kaunas, Lithuania \\ ${ }^{2}$ Vilnius Gediminas Technical University, \\ Saulètekio Ave. 11, \\ 10223 Vilnius, Lithuania
}

The method of thallium sulphide thin films deposition on low density polyethylene (LDPE), based on applying solutions of higher polythionic acids $\left(\mathrm{H}_{2} \mathrm{~S}_{n} \mathrm{O}_{6}\right.$, $n=21,33,45)$, was developed and investigated. The concentration of sulphur in the LDPE film increases with the increase of temperature of higher polythionic acid solution and its sulphurity, as well as the duration of retention of LDPE in its solution is prolonged. The sulphur concentration in the PE film under the same duration of sulphurisation and repetition of treatment cycles insignificantly changes. When the sulphurised LDPE was treated with a thallium Tl(I) salt solution, sulphur present in the polymer reacts with thallium ions and the layers of thallium sulphides, $\mathrm{Tl}_{\mathrm{x}} \mathrm{S}_{\mathrm{y}}$, of different composition are formed. The stoichiometric composition of the layer changes from $\mathrm{Tl}_{0.1} \mathrm{~S}$ to $\mathrm{Tl}_{2.6} \mathrm{~S}$. The amount of thallium increases in the sulphide layers when the number of the cycles of LDPE sulphurisation in the $\mathrm{H}_{2} \mathrm{~S}_{33} \mathrm{O}_{6}$ solution and treatment of sulphurised polymer with the $\mathrm{Tl}(\mathrm{I})$ salt solution is increased. The stoichiometric composition of $\mathrm{Tl}_{\mathrm{x}} \mathrm{S}_{\mathrm{y}}$ coats of one treatment cycle samples changes from $\mathrm{Tl}_{0.5} \mathrm{~S}_{\text {to }} \mathrm{Tl}_{1.1} \mathrm{~S}$. The X-ray diffraction analysis of the polyethylene, treated with the solution of higher polythionic acid, $\mathrm{H}_{2} \mathrm{~S}_{33} \mathrm{O}_{6}$, and then with the $\mathrm{Tl}(\mathrm{I})$ salt solution, confirmed the premise that on the LDPE surface the layers of thallium sulphides, $\mathrm{Tl}_{x} \mathrm{~S}_{y}$, were formed. Five phases of thallium sulphides were identified: $\mathrm{TlS}, \mathrm{Tl}_{2} \mathrm{~S}, \mathrm{Tl}_{2} \mathrm{~S}_{2}, \mathrm{Tl}_{4} \mathrm{~S}_{3}$ and $\mathrm{Tl}_{2} \mathrm{~S}_{5}$. The TlS phase prevailed in diffractograms. The chemical and phase composition of the $\mathrm{Tl}_{\mathrm{x}} \mathrm{S}_{\mathrm{y}}$ layers surface (up to $1 \mathrm{~nm}$ depth) is identified by X-ray photo-electronic spectroscopy analysis. The analysis data confirmed that the compounds of TlS, $\mathrm{Tl}_{2} \mathrm{~S}, \mathrm{Tl}_{2} \mathrm{SO}_{4}, \mathrm{Tl}(\mathrm{OH})_{3}, \mathrm{~S}_{8}$ and $\mathrm{Tl}_{2} \mathrm{O}_{3}$ were formed on the surface of the layers. The morphology of thallium sulphide layers and the mechanism of their formation are determined by means of scanning atomic force and electronic microscopy. Two processes take place during the formation of the layer: desorption of sulphur and reaction of thallium ions from the thallium(I) salt solution with sulphur present on the LDPE surface. The layer of thallium sulphides is formed on the surface of the sulphur layer. Deposition of thallium sulpfide films from the solution of higher polythionic acid on the LDPE films is not homogeneous, it has the separated island type morphology. The identified regularities let purposively choose the conditions for sulphurisation of LDPE films by using the solution of higher polythionic acid as the agent of polymer sulphurisation in order to compose the layers of thallium sulphides, $\mathrm{Tl}_{\mathrm{x}} \mathrm{S}_{\mathrm{y}}$, of the desired chemical and phasic composition on the surface of this polymer by means of the sorption-diffusion method.

Keywords: polyethylene, thallium sulpfide thin films, atomic force microscopy, $\mathrm{X}$-ray diffraction, X-ray photoelectron spectroscopy 


\section{INTRODUCTION}

Composite materials (composites) are distinguished by the properties of their components and are needed for advanced technologies. Modification of elastic, light and resistant to the environment polymeric materials by creating thin layers of compounds with important physical properties on their surface leads to the formation of materials with new properties [1 1 -5]. These thin layers have a number of applications in various fields, including coatings, interference filters, polarizers, narrow band filters, solar cells, photoconductors, IR detectors, waveguide coatings, magnetic and superconducting films, microelectronic devices, etc. [6-9]. Many metal sulphide compounds have excellent optical properties in the visible and IR region of the spectrum [10-17].

Recently at the Department of Inorganic Chemistry the sorption-diffusion method of low density polyethylene (LDPE) modification by semiconductor and electrically conductive layers of $\mathrm{Cu}_{x} \mathrm{~S}$ has been investigated. By means of this method, first of all, PE is saturated with sulphur treating with the solutions of higher polythionic acids, $\mathrm{H}_{2} \mathrm{~S}_{n} \mathrm{O}_{6}(n=9-45)$ [18, 19], and then it is treated with a water solution of copper (II/I) salts [20-35].

The layers of thallium sulphides are distinguished by a great variety of stoichiometry and valuable physical properties. The layers of thallium sulphides are commonly produced by the deposition method from solutions [36 41]. But its formation is more convenient by the use of sorption methods.

The aim of the present work was to summarize and to discuss the results obtained by us studying the formation and characterization of thallium sulphide layers on LDPE films surface by the sorption-diffusion method, since mainly only separate fragments of these studies in our previous publications have been described [42-50].

\section{EXPERIMENTAL}

The layer of thallium sulpfide was deposited on the films of low density polyethylene (LDPE) (GOST 10354-82), produced at Vilnius Pastic Plant 'Plasta. The thickness of the LDPE film was $0.22 \pm 0.01 \mathrm{~mm}$. Before experimentation the $15 \times 75 \mathrm{~mm}$ samples of LDPE were accordingly prepared. They were washed for $10 \mathrm{~min}$ by a $4 \%$ solution of a cationic surfactant, degreased in benzene for $10 \mathrm{~min}$. The extracted samples were washed in distilled water and dried. Distilled water, reagents of the grades 'especially pure', 'chemically pure' and 'analytically pure' were used in the experiments.

The samples of LDPE were sulphured in $0.002 \mathrm{~mol} \cdot \mathrm{dm}^{-3}$ stirred in the solutions of higher polythionic acids $\left(\mathrm{H}_{2} \mathrm{~S}_{n} \mathrm{O}_{6}\right.$, $n=21,33,45)$ at $25,40,60$ and $80^{\circ} \mathrm{C}$. Then these solutions were kept in the darkness in an open vessel for $48 \mathrm{~h}$ until hydrogen sulphide removed fully [51].
The solution of thallium(I) salt was made from crystaline thallium(I) sulphate. The concentration of thallium(I) sulphate solutions was $0.01,0.05$ and $0.1 \mathrm{~mol} \cdot \mathrm{dm}^{-3}(\mathrm{pH}$ $\sim 2.8$ ) with addition of $0.015 \mathrm{~mol} \cdot \mathrm{dm}^{-3} \mathrm{KOH}(\mathrm{pH} \sim 11.4)$. When using alkalified thallium(I) salt, thallium sulphide layers on the surface of LDPE were obtained [40, 45]. For the formation of $\mathrm{Tl}_{\mathrm{x}} \mathrm{S}_{\mathrm{y}}$ films, the sulphured LDPE samples were treated with the $\mathrm{Tl}(\mathrm{I})$ salt solution at $80^{\circ} \mathrm{C}$.

The concentration of diffused sulphur into LDPE was determined by several methods. The sulfur was extracted with acetone and the content in the extract was determined by the spectrometric cyanide method using a Specord UV/VIS spectrophotometer $(\lambda=450 \mathrm{~nm})$ [52]. The concentration of sulphur with more thick $\mathrm{Tl}_{x} \mathrm{~S}_{\mathrm{y}}$ layers, which have been obtained repeating 3 times the sulphurisation of LDPE, was determined by the nephelometric method, using an atomic absorption spectrophotometer Perkin-Elmer 503 $(\lambda=553.6 \mathrm{~nm})$, indirectly by the measurements of $\mathrm{Ba}^{2+}$ ions after sulphur deposition in the form of $\mathrm{BaSO}_{4}[53]$.

The amount of Tl in LDPE was determined using an atomic absorption spectrophotometer Perkin-Elmer 503 $(\lambda=276.5 \mathrm{~nm})[53]$.

The phase composition of thallium sulphides layers on the surface of LDPE was investigated by means of X-ray diffraction (XRD) with a DRON-6 diffractometer provided with a special device for beam limitation at low and medium diffraction angles using a graphite-monochromatized $\mathrm{Cu}$ $\mathrm{Ka}$ radiation source $(\lambda=1.54178 \AA$ ) under $30 \mathrm{kV}$ voltage and $30 \mu \mathrm{A}$ current. The XRD patterns were recorded with a step size of $0.05^{\circ}$ from $2 \theta=10^{\circ}$ to $70^{\circ}$. X-ray diffractograms of LDPE samples with the layers of thallium sulphides were treated using the program Search Match to eliminate the maxima of LDPE. The experimental XRD patterns with the layers of $\mathrm{Tl}_{x} \mathrm{~S}_{y}$ analysis were performed using the Crystallografica software and PDF data base [17, 37, 54, 55].

The chemical composition of thallium sulphides layers was investigated by the method of X-ray photoelectron spectroscopy (XPS). Spectrums were recorded by means of a spectrometer ESCALAB MKII, produced at VG Scientific (England), the power of which is $300 \mathrm{~W}$, applying the radiation of $\mathrm{Mg}$ anode ( $\mathrm{Mg} \mathrm{Ka} 1253.6 \mathrm{eV}$, capacity $300 \mathrm{~W}$ ). In the analytic chamber the vacuum of $1.33 \cdot 10^{-8} \mathrm{~Pa}$ was maintained. In order to identify the distribution of elements by depth, the searchlight of $\mathrm{Ar}^{+}$ions, the ions flow energy of which is approximately $1.0 \mathrm{keV}$, was applied. The samples were etched in a preparatory chamber under $9.31 \cdot 10^{-3} \mathrm{~Pa}$ vacuum and $20 \mu \mathrm{A}$ current, this corresponds to $20 \AA \mathrm{m} / \mathrm{min}$ etching speed. The etching time was $10 \mathrm{~s}$. To investigate the layers obtained by the XPS method the photoelectron spectra of $\mathrm{Tl} 4 \mathrm{f}_{7 / 2}, \mathrm{O} 1 \mathrm{~s}$ and $\mathrm{S} 2 \mathrm{p}$ were recorded. Empirical sensitivity factors for these elements were taken from the literature [56-58] and the spectra obtained were compared with the standard ones [59].

The morphology of the surface of $\mathrm{Tl}_{x} \mathrm{~S}_{y}$ layers was investigated by atomic force microscopy (NT-MDT Inc., 
Zelenograd, Moscow, Russia) in the contact mode using commercial (Nano Technology Instruments - Europe BV) Si cantilevers CSG10 series with $0.2 \mathrm{Nm}^{-1}$ force constant and $10 \mathrm{~nm}$ tip curvature. The data of measurements were analysed by means of the programs Scan Atomic ${ }^{\mathrm{TM}}$, SPIP.

\section{RESULTS AND DISCUSSION}

\section{The preparation of layers of thallium sulphides by sorption-diffusion on the surface of LDPE}

The formation of thallium sulphide, $\mathrm{Tl}_{\mathrm{x}} \mathrm{S}_{\mathrm{y}}$, layers on the LDPE surface consists of two parts. During the first part of the process the samples of LDPE were sulphured in a water solution of higher polythionic acids $\mathrm{H}_{2} \mathrm{~S}_{n} \mathrm{O}_{6}(n=21,33$, 45) as a chalcogenization agent. The molecules of elemental sulphur are formed during the decomposition of higher polythionic acids and are then sorbed-diffused into the matrix of the LDPE surface [60].

During the second part of this process the sulphured samples are treated with a water solution of Tl(I) salt. Thallium sulphide layers on the LDPE surface are formed by the sorption-diffusion method as a result of the oxidationreduction reaction between sulphur firstly sorbed-diffused in LDPE and $\mathrm{Tl}^{+}$ions present in a solution of thallium(I) salt [45, 50, 61]. Two processes take place during the formation of the thallium sulphide film on the surface of LDPE: elemental sulphur desorption and interaction of $\mathrm{Tl}^{+}$with elemental sulphur in the solution.

\section{Sulphurisation of polyethylene by solutions of higher polythionic acids $\mathrm{H}_{2} \mathrm{~S}_{n} \mathrm{O}_{6}$}

The samples of the LDPE film were sulphurised in solutions of higher $\mathrm{H}_{2} \mathrm{~S}_{n} \mathrm{O}_{6}(n=21,33,45)$ at $60^{\circ} \mathrm{C}$ temperature. It was known that the molecules of elemental sulfur are formed during the decomposition of higher polythionic acids. The concentration of sulfur adsorbed-diffused into LDPE depends on the degree of acid sulphurity $(n)$, the temperature of the solution and the period of polymer treatment [19, 51].

The sorption-diffusion of sulphur from solutions of higher polythionic acids, $\mathrm{H}_{2} \mathrm{~S}_{21} \mathrm{O}_{6}$ and $\mathrm{H}_{2} \mathrm{~S}_{45} \mathrm{O}_{6}$, at $60^{\circ} \mathrm{C}$ temperature, and of $\mathrm{H}_{2} \mathrm{~S}_{33} \mathrm{O}_{6}$ acid at $25,40,60$ and $80^{\circ} \mathrm{C}$ temperatures was investigated. The process of LDPE sulphurisation lasted up to $3 \mathrm{~h}$. The samples of polymer were taken out from the solution of a sulphurisation agent in certain time intervals.

We found that when the sulphurity of $\mathrm{H}_{2} \mathrm{~S}_{n} \mathrm{O}_{6}(n)$ increased, the concentrations of $S\left(c, \mathrm{mg} \cdot \mathrm{cm}^{-3}\right)$ in LDPE increased too. But a more marked influence on the value of sulphur sorbed-diffused into LDPE has the increase of the number of sulphur atoms in the molecule of $\mathrm{H}_{2} \mathrm{~S}_{n} \mathrm{O}_{6}$ from $n=33$ to $n=45$.

The sulphur concentration in LDPE was increased during the first hour of the polymer sulphurisation process in the $\mathrm{H}_{2} \mathrm{~S}_{n} \mathrm{O}_{6}$ solutions. Further on prolonging the duration of sulphurisation, the sulphur concentration increased more slowly in LDPE, however, the saturated concentration was inaccessible even during $3 \mathrm{~h}$ (Fig. 1).

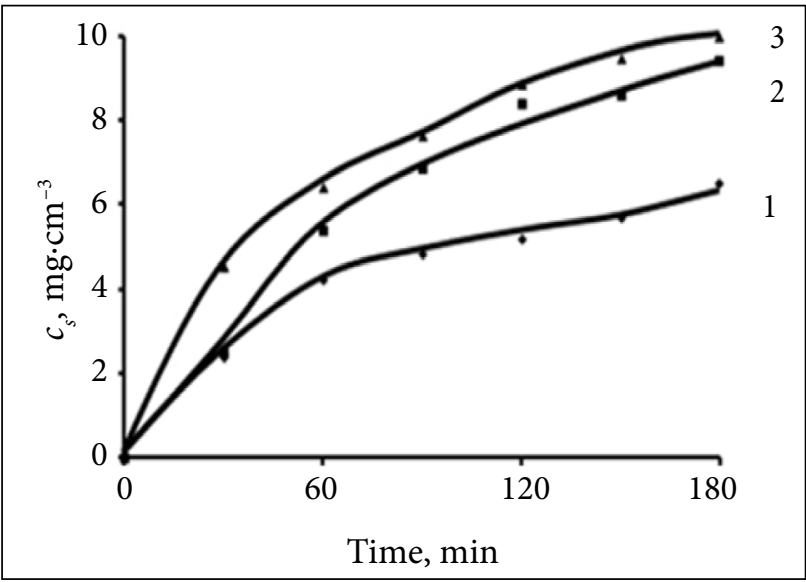

Fig. 1. Changes of the sulphur concentration in LDPE with time during its treatment in the solutions of $\mathrm{H}_{2} \mathrm{~S}_{\mathrm{n}_{6}}$ at $60^{\circ} \mathrm{C}$ temperature. The average number of sulphur atoms $n$ in a polythionic acid molecule: 21 (1), 33 (2) and 45 (3)

Thus, these results reveal that the solutions of higher polythionic acid $\mathrm{H}_{2} \mathrm{~S}_{33} \mathrm{O}_{6}$ are suitable to be applied for LDPE sulphurisation during further research, as a further increase of the sulphurisation degree (the number of $\mathrm{S}$ atoms in a molecule, $n$ ) does not make a more distinguished influence upon the effectiveness of LDPE sulphurisation. Figure 2 presents the change of sulphur concentration in the LDPE film when the samples are sulphured in the $\mathrm{H}_{2} \mathrm{~S}_{33} \mathrm{O}_{6}$ acid solution during different periods of time at $25,40,60$ and $80^{\circ} \mathrm{C}$ temperature.

The kinetic curves of sulphur concentration changes show that the concentration of sulphur sorbed-diffused

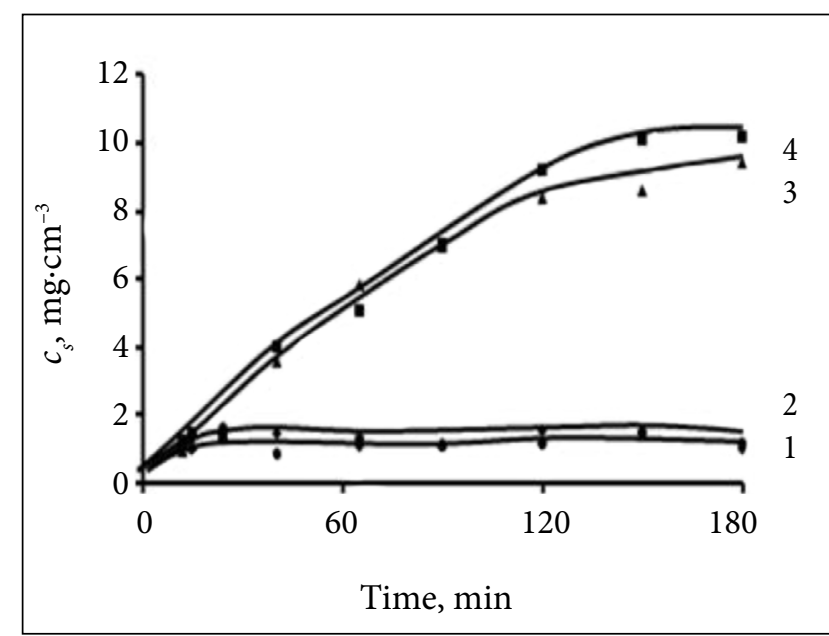

Fig. 2. Changes of the sulphur concentration in LDPE with time during its treatment in the $\mathrm{H}_{2} \mathrm{~S}_{33} \mathrm{O}_{6}$ solution. The temperature of the solution, ${ }^{\circ} \mathrm{C}: 25$ (1), 40 (2), $60(3), 80(4)$ 
into LDPE increases with the sulphurisation time at all temperatures used. But the rise of the temperature from 40 to $60^{\circ} \mathrm{C}$ makes a vivid influence on the values of sulphur concentration, $c_{s}$, achieved in the polymer films. The saturated sulphur concentration in LDPE at $25^{\circ} \mathrm{C}$ temperature was reached after $1 \mathrm{~h}$ and at $40^{\circ} \mathrm{C}$ temperature it was reached after $2 \mathrm{~h}$ of treatment. While the samples of LDPE were treated in the $\mathrm{H}_{2} \mathrm{~S}_{33} \mathrm{O}_{6}$ solution at 60 and $80^{\circ} \mathrm{C}$ temperature, the saturated $c_{s}$ was reached after $\sim 2.5 \mathrm{~h}$.

Thus our experimentations showed that the LDPE sulphurisation was purposive to be performed in the $\mathrm{H}_{2} \mathrm{~S}_{33} \mathrm{O}_{6}$ solution at $60^{\circ} \mathrm{C}$ temperature during further research.

\section{Formation of thallium sulphide layers on the sulphurised surface of LDPE by applying \\ thallium(I) salt solutions}

The second part of LDPE modification is the reaction of a sulphurised film with a solution of $\mathrm{Tl}(\mathrm{I})$ sulphate and formation of $\mathrm{Tl}_{x} \mathrm{~S}_{y}$ layers on the LDPE surface.

The $\operatorname{Tl}_{x} S_{y}$ layer on the surface of the LDPE film is formed when $\mathrm{Tl}^{+}$ions react with sorbed-diffused sulphur in the polymer. Thallium sulphide layers are formed in the surface of LDPE as a result of the oxidation-reduction reaction between sulphur sorbed by LDPE and thallium(I) ions present in the solution of thallium(I) salt [45]:

$$
3 \mathrm{xTl}^{+}+1 / 8 \mathrm{~S}_{8} \rightarrow \mathrm{Tl}_{2 \mathrm{x}} \mathrm{S}+\mathrm{xTl}^{1+}
$$

$\mathrm{Tl}^{+}$ions have higher mobility than $\mathrm{S}_{8}$ molecules, and this $\mathrm{Tl}_{\mathrm{x}} \mathrm{S}_{\mathrm{y}}$ layer is formed when $\mathrm{Tl}^{+}$ions diffuse into the sulphurised LDPE. Low-density polyethylene consists of unevenly distributed amorphous and crystal areas. Sorptiondiffusion of sulphur as well as of $\mathrm{Tl}^{+}$ions is possible only in amorphous areas of LDPE. The product of the reaction impedes further diffusion of $\mathrm{Tl}^{+}$ions into the depth of the polymer, but there are enough defects of the structure in LDPE, where diffusion of small molecule compounds occurs even through the formed layer of $\mathrm{Tl}_{x} \mathrm{~S}_{\mathrm{y}}$. By the changed colour of the LDPE film it is possible to judge that, after processing the sulphurised LDPE with the Tl(I) solution, the layer of thallium sulphides is formed on its surface [62]. The colour of LDPE films directly depends on the conditions of sulphurisation. The LDPE films, whose concentration of diffused sulphur was small, become redly brownish after 'thalliumisation', and the films, whose concentration of sulphur was larger, after the reaction with the $\mathrm{Tl}(\mathrm{I})$ solution become dust-coloured or even blackish.

The amount of thallium in the polymer is influenced by the processes of LDPE sulphurisation and treatment with the $\mathrm{Tl}_{2} \mathrm{SO}_{4}$ salt solution.

It was found that the amount of thallium in the sulphide layers on the LDPE surface increased with the prolongation of LDPE sulphurisation in the $\mathrm{H}_{2} \mathrm{~S}_{33} \mathrm{O}_{6}$ solution at all used temperatures. A different amount of thallium was found in the $\mathrm{Tl}_{\mathrm{S}}$ layers on the surface of LDPE at every temperature [45]. The maximum value of the $\mathrm{Tl}$ amount depends on the temperature of the sulphurisation solution (Fig. 3).

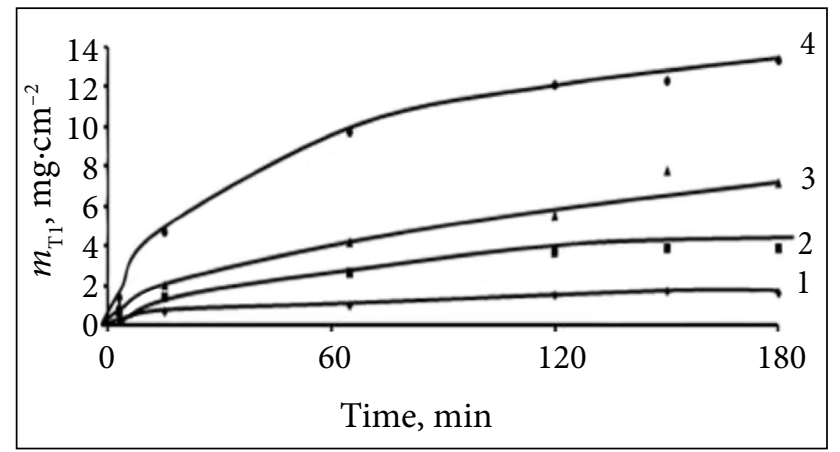

Fig. 3. Changes of the thallium concentration in the TI $\mathrm{S}_{x}$ layer. LDPE was sulphurised in the $\mathrm{H}_{2} \mathrm{~S}_{33} \mathrm{O}_{6}$ solution, then treated with the $0.1 \mathrm{~mol} \cdot \mathrm{dm}^{-3}$ solution of $\mathrm{Tl}_{2} \mathrm{SO}_{4}$ at $80^{\circ} \mathrm{C}$ temperature for $10 \mathrm{~min}$. The temperature of the sulphurisation solution, ${ }^{\circ} \mathrm{C}: 25$ (1), 40 (2), 60 (3), 80 (4)

The amount of thallium directly depends on the sulphur concentration in LDPE, i.e. when the latter increases, the amount of $\mathrm{Tl}$ also increases in the obtained layer on the LDPE surface (Fig. 4). This is quite understandable because if the concentration of sorbed-diffused sulphur is higher, a greater amount of $\mathrm{Tl}^{+}$ions can take part in the oxidation-reduction reaction with sulphur molecules.

The influence of experimental conditions (temperature, concentration and duration of LDPE sulphurisation and the treatment of sulphurised LDPE with thallium(I) salt solution) on the thallium sulpfide layers in the LDPE surface was studied. The obtained results show that $m_{\mathrm{TI}}$ constantly increases when the temperature of 'thalliumisation' is increased (Figs. 5, 6). The maximum amounts of thallium are obtained when sulphurised LDPE is 'thalliumised' in the solution of thallium (I) salt at $80^{\circ} \mathrm{C}$ temperature. The amount

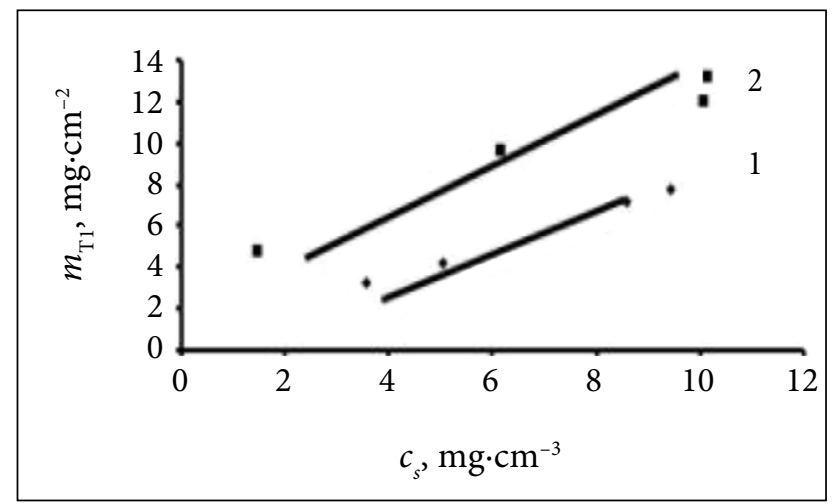

Fig. 4. Changes of the amount of thallium in the $T_{x} S_{y}$ layer on the sulphur concentration in the LDPE film. LDPE was sulphurised for $10 \mathrm{~min}$, then treated with the $0.1 \mathrm{~mol} \cdot \mathrm{dm}^{-3} \mathrm{TI}_{2} \mathrm{SO}_{4}$ solution at $80^{\circ} \mathrm{C}$ temperature. The temperature of the $\mathrm{H}_{2} \mathrm{~S}_{33} \mathrm{O}_{6}$ solution, ${ }^{\circ} \mathrm{C}: 60$ (1) and 80 (2) 


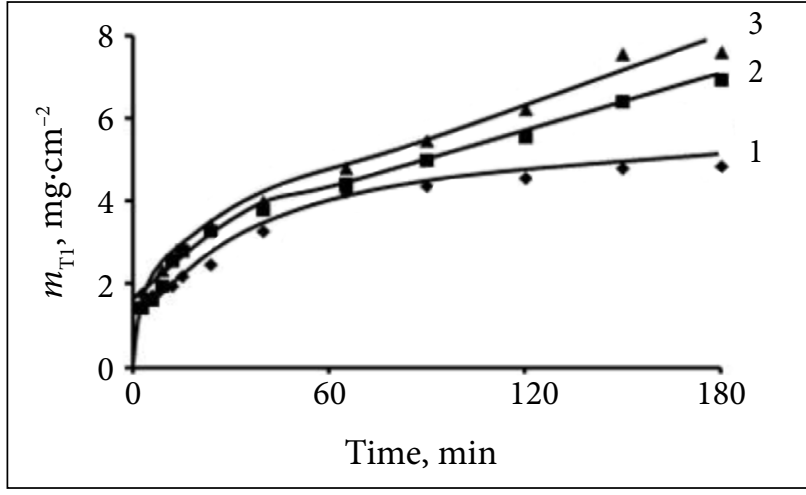

Fig. 5. Changes of the amount of thallium in the $T I_{x} S_{y}$ layer on the sulphurisation duration of the LDPE film. LDPE was sulphurised in the solution of $\mathrm{H}_{2} \mathrm{~S}_{33} \mathrm{O}_{6}$ at $60^{\circ} \mathrm{C}$ temperature, then for 10 min treated with the alkalified $\mathrm{TI}_{2} \mathrm{SO}_{4}$ solution at $80^{\circ} \mathrm{C}$ temperature. The concentration of the $\mathrm{TI}_{2} \mathrm{SO}_{4}$ solution, $\mathrm{mol} \cdot \mathrm{dm}^{-3}: 0.01$ (1), 0.05 (2) and 0.1 (3)

of thallium in the $\mathrm{Tl}_{x} \mathrm{~S}_{y}$ layer increases unevenly as it depends on the temperature of LDPE sulphurisation. When the LDPE samples are sulphurised at $60^{\circ} \mathrm{C}$ temperature, $m_{\mathrm{Tl}}$ hardly depends on the concentration of the thallium(I) salt solution (Fig. 5).

When the LDPE film samples are sulphurised at $80^{\circ} \mathrm{C}$ temperature, the concentration of the $\mathrm{Tl}_{2} \mathrm{SO}_{4}$ solution more influences the thallium amount in the $\mathrm{Tl}_{x} \mathrm{~S}_{y}$ layers (Fig. 6).

If we prolong the 'haliuminisation' of the sulphurised LDPE film with the thallium(I) salt solution, the amount of thallium in the $\mathrm{Tl}_{x} \mathrm{~S}_{y}$ layers will increase. Changes of the amount of thallium in the $\mathrm{Tl}_{x} \mathrm{~S}_{y}$ layers are shown in Fig. 凤.

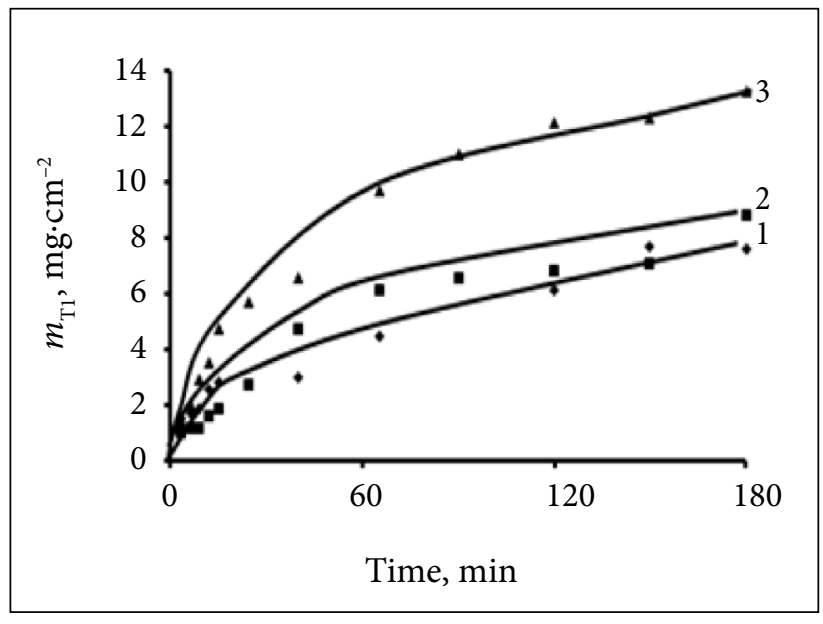

Fig. 6. Changes of the amount of thallium in the TI $\mathrm{S}_{\mathrm{y}}$ layer on the sulphurisation duration of the LDPE film. LDPE was sulphurised in the solution of $\mathrm{H}_{2} \mathrm{~S}_{33} \mathrm{O}_{6}$ at $80^{\circ} \mathrm{C}$ temperature, then treated for 10 min with the alkalified $\mathrm{TI}_{2} \mathrm{SO}_{4}$ solution at $80^{\circ} \mathrm{C}$ temperature. The concentration of the $\mathrm{Tl}_{2} \mathrm{SO}_{4}$ solution, $\mathrm{mol} \cdot \mathrm{dm}^{-3}: 0.01$ (1), 0.05 (2) and 0.1 (3)
The prolongation of sulphurisation and the repetition of treatment cycles influences the amount of thallium in the $\mathrm{Tl}_{\mathrm{x}} \mathrm{S}_{\mathrm{y}}$ layers quite differently.

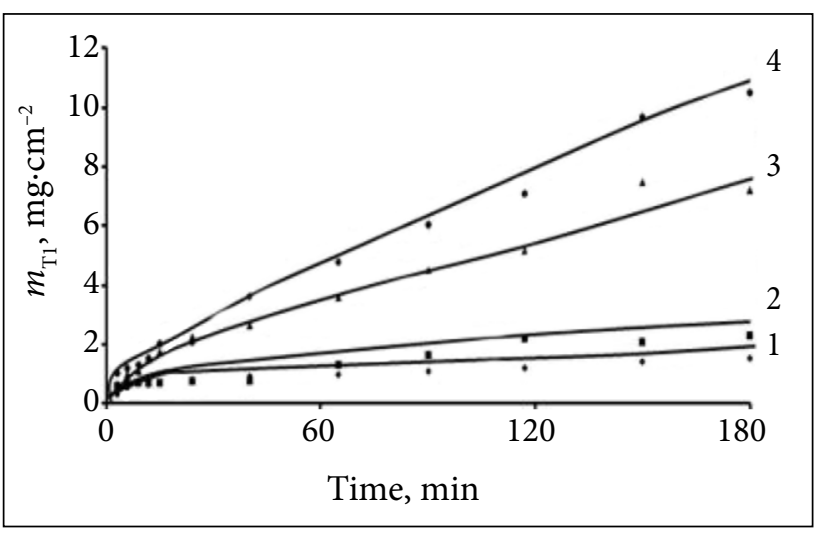

Fig. 7. Changes of the amount of thallium in the TI $\mathrm{S}_{\mathrm{y}}$ layer on the sulphurisation duration of the LDPE film. LDPE was sulphurised in the solution of $\mathrm{H}_{2} \mathrm{~S}_{33} \mathrm{O}_{6}$ at $60^{\circ} \mathrm{C}$ temperature, then treated with the alkalified $0.1 \mathrm{~mol} \cdot \mathrm{dm}^{-3} \mathrm{TI}_{2} \mathrm{SO}_{4}$ solution at $80^{\circ} \mathrm{C}$ temperature. The duration of the treatment of sulphurised LDPE with the $\mathrm{Tl}_{2} \mathrm{SO}_{4}$ solution, $\min : 2$ (1), 5 (2), 10 (3) and 20 (4)

Considering that the cycles of the process of $\mathrm{Tl}_{x} \mathrm{~S}_{y}$ layers formation can give a positive result, for example, to obtain thicker sulphide layers better cohered with polymer, we further investigated how concentrations of sulphur and thallium in LDPE change after each cycle. Thicker layers were obtained by repeating the cycles of sulphurisation and treatment with the thallium(I) salt solution for three times, i.e. sulphurisation-'thalliumisation', then sulphurisation of the same sample of the PE film and 'thalliumisation', etc.

The solutions of higher polythionic acid $\mathrm{H}_{2} \mathrm{~S}_{33} \mathrm{O}_{6}$ at $60^{\circ} \mathrm{C}$ temperature for this experimentation were used. The presented data show that the sulphur concentrations in the LDPE film, which was kept in $\mathrm{H}_{2} \mathrm{~S}_{33} \mathrm{O}_{6}$ solutions for different time intervals, increase as well. During the first cycle, in $15 \mathrm{~min}$ from the experiment beginning, the sulphur concentration equals $c_{s} \sim 1.95 \mathrm{mg} \cdot \mathrm{cm}^{-3}$, after $2 \mathrm{~h}$ the $S$ concentration increases $\sim 4$ times and is equal to $c_{s} \sim 7.65 \mathrm{mg} \cdot \mathrm{cm}^{-3}$. By repetition of sulpharisation cycles, in the LDPE samples of two cycles of the treatment, sulphurised for $15 \mathrm{~min}$, $c_{s}$ is equal to $\sim 2 \mathrm{mg} \cdot \mathrm{cm}^{-3}$, it is 1.5 times larger after $30 \mathrm{~min}$ and 2.5 times larger after $60 \mathrm{~min}$. The sulphur concentration of three treatment cycles as well as one cycle in the LDPE samples of sulphurisation for $120 \mathrm{~min}$ is four times larger than in the sulphurised samples for $15 \mathrm{~min}$ (Fig. 8). Thus the sulphurisation duration makes a great influence upon the sulphur concentration in the LDPE film.

It is supposed that by repeating the cycles a moderate part of $\mathrm{S}_{8}$ segregated in the solution of polythionic acid absorbs on the coat surface or reacts with the composed layer of thallium sulphide: 


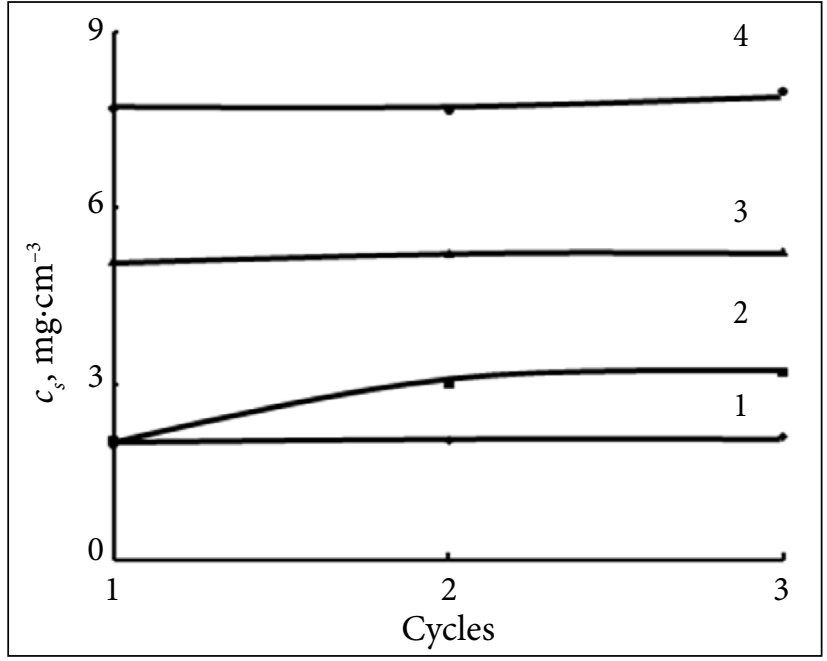

Fig. 8. Changes of the sulphur concentration in LDPE on the number of cycles of its treatment in the $\mathrm{H}_{2} \mathrm{~S}_{33} \mathrm{O}_{6}$ solution. The sulphurisation duration of LDPE, min: $15(1), 30(2), 60(3)$ and 120 (4)

$$
(\mathrm{y}-\mathrm{x}) / 8 \mathrm{~S}_{8}+\mathrm{xTl} \mathrm{y}_{\mathrm{y}} \rightarrow \mathrm{yTl} \mathrm{x} .
$$

The results of the research permit to state that compounds possessing thallium and sulphur, i.e. layers of thallium sulphides, are formed on the surface of the PE film, first affected with solutions of higher polythionic acid $\mathrm{H}_{2} \mathrm{~S}_{33} \mathrm{O}_{6}$, and later with that of $\mathrm{Tl}(\mathrm{I})$ salt.

\section{The morphology of $\mathrm{Tl}_{x} \mathrm{~S}_{\mathrm{y}}$ layers on the surface of LDPE}

To characterize the morphology of $\mathrm{Tl}_{x} \mathrm{~S}_{y}$ layers on the surface of LDPE, the method of atomic force microscopy (AFM) was applied. Fields of $30 \times 30$ microns were investigated; for the quantitative estimation of the surface, the standard programs of the view treatment were used. Figures 9 shows the typical surface morphology of the deposited sulphur and thallium sulpfide thin films on the LDPE surface obtained by AFM.

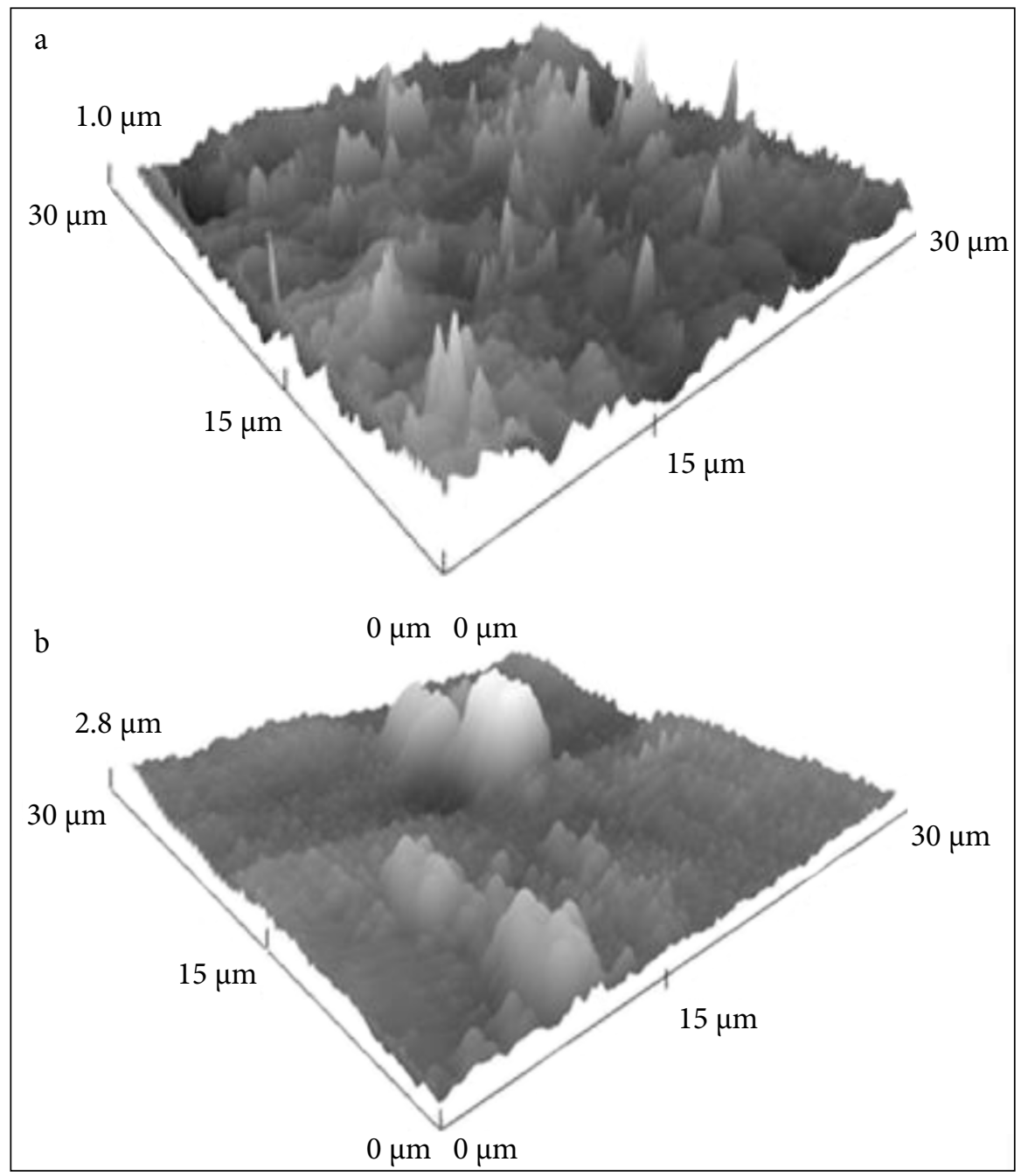

Fig. 9. The study of the morphology of $T I_{x} S_{y}$ layers on the LDPE surface by AFM: LDPE sulphurised during $12 \mathrm{~min}$ in the solution of $\mathrm{H}_{2} \mathrm{~S}_{33} \mathrm{O}_{6}$ at $60^{\circ} \mathrm{C}$ temperature (a); sulphurised LDPE treated with the $0.1 \mathrm{~mol} \cdot \mathrm{dm}^{-3}$ solution of $\mathrm{Tl}_{2} \mathrm{SO}_{4}$ at $80^{\circ} \mathrm{C}$ temperature during $1 \mathrm{~min}$ (b) 
Two processes take place during the formation of the layer: desorption of sulphur and reaction of thallium ions from the thallium(I) salt solution with the sulphur present on the LDPE surface. The layer of thallium sulphides is formed on the surface of the sulphur layer. Deposition of thallium sulpfide films from the solution of higher polythionic acid on the LDPE films is not homogeneous and has the separated island type morphology.

The inhomogeneous film structure is related to the LDPE film surface structure and islands of different PE crystallization direction. The treatment of LDPE films with the sulphur layer in the $\mathrm{Tl}_{2} \mathrm{SO}_{4}$ solution does change significantly the structure and roughness of the films, but the average roughness and film thickness are higher when compared with the sulphur films.

\section{XRD characterization}

The phase composition of thallium sulphides could be qualitatively and semiquantitatively characterized by the X-ray diffraction. It is not easy to identify the structure of thallium sulphide layers on the polymeric surface due to the peculiarities of composition materials: polycrystallinity of layers; existence of several phases of $\mathrm{Tl}_{x} \mathrm{~S}_{y}$, which have different composition and structure; a crystal structure of a polymeric film. Despite the mentioned difficulties, the phasic composition of the layer of thallium sulphides on the PE surface was analysed by the method of X-ray diffraction analysis [56, 57, 59].

The peak of the monoclinic TIS phase predominates in the diffractograms of obtained $\mathrm{Tl}_{x} \mathrm{~S}_{\mathrm{y}}$ layers when the LDPE films were sulphured in the solution of $\mathrm{H}_{2} \mathrm{~S}_{33} \mathrm{O}_{6}$ during 15,60 and $120 \mathrm{~min}$ at $60^{\circ} \mathrm{C}$ temperature (Fig. 10). A strong peak of the TIS (223) phase is seen in the diffractograms at $2 \Theta=24.18^{\circ}$ (corresponding to interplanar spacing $d=3.69 \AA$ ). The peak of the $\operatorname{TlS}(130)$ phase at $2 \Theta=25.6^{\circ}$ (corresponding to $d=3.48 \AA$ ) is also observed in the diffractograms of these samples. The peaks of another two thallium sulphide phases in the diffractograms of LDPE samples initially sulfured during $120 \mathrm{~min}$ are observed (Fig. 10, Curve 3): tetragonal $\mathrm{Tl}_{2} \mathrm{~S}_{2}$ at $2 \Theta=11.9,31.2$ and $46.9^{\circ}$ (corresponding to $d=7.3,2.87$ and $1.955 \AA$ ) and rhombohedral $\mathrm{Tl}_{2} \mathrm{~S}$ at $2 \Theta=29.4$ and $49.36^{\circ}$ (corresponding to $d=2.9$ and $1.79 \AA$ ).

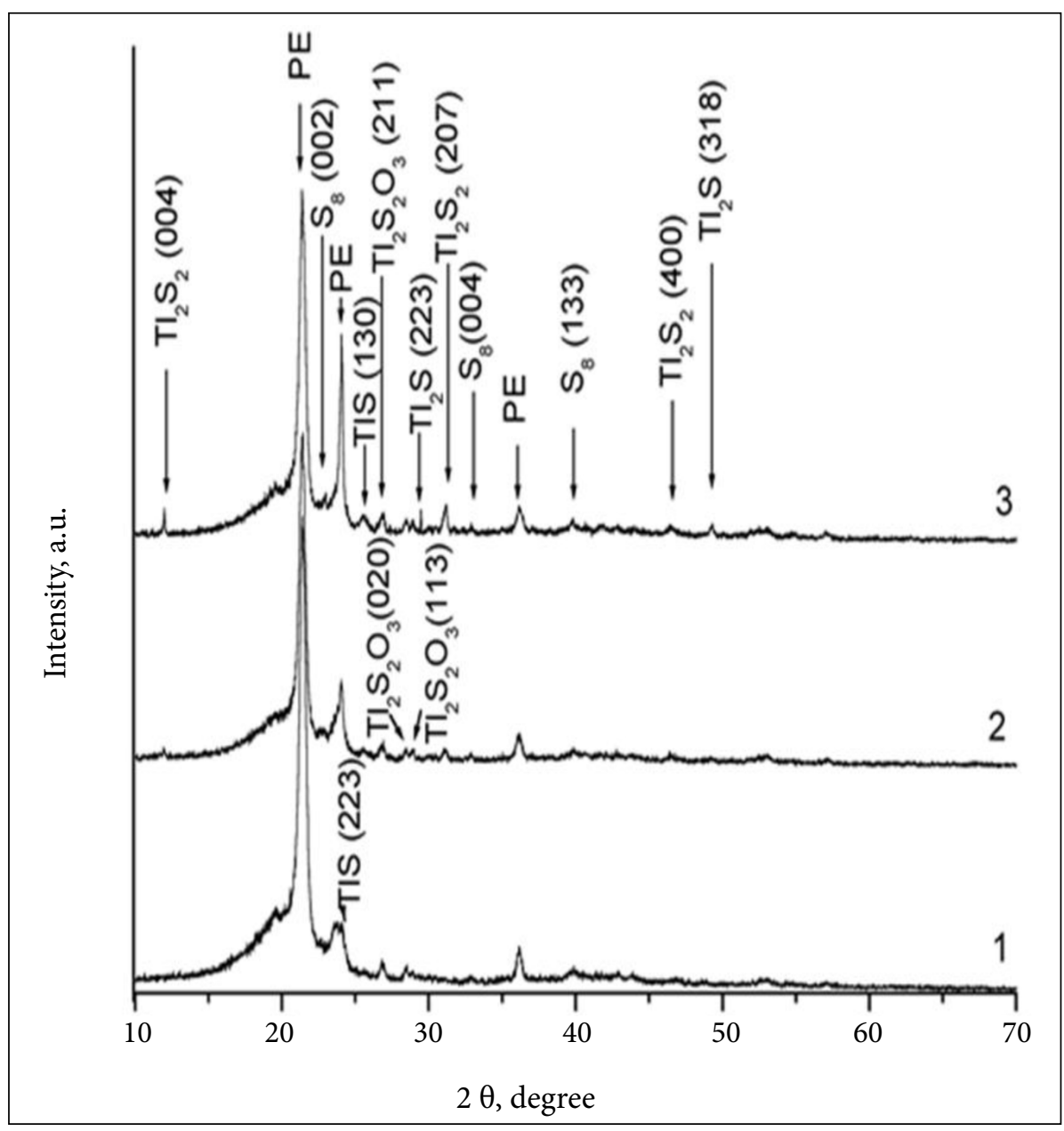

Fig. 10. X-ray diffraction patterns of thallium sulpfide layers on the surface of LDPE. LDPE initially treated with a solution of $\mathrm{H}_{2} \mathrm{~S}_{33} \mathrm{O}_{6}$ at $60^{\circ} \mathrm{C}$ at different time and then with the $\mathrm{TI}_{2} \mathrm{SO}_{4}$ solution at $80^{\circ} \mathrm{C}$ for $10 \mathrm{~min}$. The sulphurisation time, $\min : 15(1), 60(2)$ and $120(3)$ 
In the case of LDPE treated with the solution of $\mathrm{H}_{2} \mathrm{~S}_{33} \mathrm{O}_{6}$ at $60^{\circ} \mathrm{C}$ at different time and then with the $\mathrm{Tl}_{2} \mathrm{SO}_{4}$ solution at $80^{\circ} \mathrm{C}$ for $10 \mathrm{~min}$, five phases TIS, $\mathrm{Tl}_{2} \mathrm{~S}, \mathrm{Tl}_{2} \mathrm{~S}_{2}, \mathrm{Tl}_{2} \mathrm{~S}_{2} \mathrm{O}_{3}$ and $\mathrm{S}_{8}$ were identified by the $\mathrm{X}$-ray difraction analysis in the thallium sulpfide layers.

The phasic composition of the $\mathrm{Tl}_{x} \mathrm{~S}_{y}$ layers, made by repeating cycles of sulphurisation and treatment with the thallium(I) salt solution for three times, was also identified by the X-ray diffraction analysis. The research results showed that by repeating the treatment cycles of LDPE, three phases of thallium sulphides were identified in the diffractograms: $\mathrm{TlS}, \mathrm{Tl}_{2} \mathrm{~S}$ and $\mathrm{Tl}_{2} \mathrm{~S}_{2}$. In the diffractograms the peaks of TIS and Tl2S phases, getting more intensified when the duration of LDPE sulphurisation is prolonged and the number of treatment cycles is increased, are most intensive.

\section{XPS characterization}

Later the coat surface is etched by $\mathrm{Ar}^{+}$ions up to $1 \mathrm{~nm}$ depth and again it is investigated. This analysis is limited only in the research of the chemical and phasic composition of a very thin $(1 \mathrm{~nm}) \mathrm{Tl}_{\mathrm{x}} \mathrm{S}_{y}$ layer as the thickness of all layer reaches several tens of $\mu \mathrm{m}$. Considering the data obtained by the XPS method - atomic percentage of elements, bond energies and separate elements $\mathrm{Tl} 4 \mathrm{f}_{7 / 2}, \mathrm{O}$ 1s and S $2 \mathrm{p}$ spectrums - we were seeking to identify the composition of the $\mathrm{Tl}_{\mathrm{x}} \mathrm{S}_{\mathrm{y}}$ layers [58].

By means of the XPS method we identified that on the polymer surface the layer consisting of different thallium, sulphur and oxygen compounds is formed. The following compounds were identified: $\mathrm{TlS}, \mathrm{Tl}_{2} \mathrm{~S}, \mathrm{Tl}_{2} \mathrm{SO}_{4}, \mathrm{Tl}(\mathrm{OH})_{3}, \mathrm{~S}_{8}$ and $\mathrm{Tl}_{2} \mathrm{O}_{3}$. The study of $\mathrm{Tl}, \mathrm{S}, \mathrm{O}$ element distribution in $\mathrm{Tl}_{\mathrm{x}} \mathrm{S}_{\mathrm{y}}$ layers revealed that oxygen (30-57 at.\%) made the largest part on the surface of all samples of the PE film. During the formation of $\mathrm{Tl}_{\mathrm{x}} \mathrm{S}_{\mathrm{y}}$ layers on the PE surface all processes take place in the open environment, so it is impossible to avoid environment influence upon the chemical composition of the obtained layers and on the surface of thallium sulphide layers oxygen can always be detected. As metal sulphides, when getting them in the matrix of the polymer surface by the sorption-diffusion method, are formed in the shape of dendrites, so among the dendrites one can detect adsorbed hardly soluble $\mathrm{Tl}_{2} \mathrm{SO}_{4}$. In addition, if the oxidation-reduction reaction when thallium(I) ions react with element sulphur occurs, thallium(III) ions make insoluble $\mathrm{Tl}(\mathrm{OH})_{3}$ together with the present groups of $\mathrm{HO}^{-}$in alkalified $\mathrm{Tl}_{2} \mathrm{SO}_{4}$. In deeper layers oxygen can be interlinked into $\mathrm{Tl}_{2} \mathrm{O}_{3}$. The layers of $\mathrm{Tl}_{\mathrm{x}} \mathrm{S}_{\mathrm{y}}$ on the polymer surface are formed in islets because the diffusion of sulphur and thallium(I) ions is possible only in amorphous areas of PE, and atmospheric oxygen faces no difficulties to approach the latter.

When the surface of the layer is etched by $\mathrm{Ar}^{+}$ions, the amount of oxygen considerably decreases (0-20 at.\%). This proves that in the mentioned compounds a greater part of oxygen is found only on the surface.
The data of XPS analysis show that the composition of the $\mathrm{Tl}_{\mathrm{x}} \mathrm{S}_{\mathrm{y}}$ layers formed under different conditions is very similar. Thus the research performed by the RFES method confirms the results obtained by the X-ray diffraction research of the $\mathrm{Tl}_{x} \mathrm{~S}_{\mathrm{y}}$ layers - the formation of thallium sulphides of different phases in the layers of $\mathrm{Tl}_{\mathrm{x}} \mathrm{S}_{\mathrm{y}}$ on the PE surface.

Received 23 July 2018 Accepted 5 September 2018

\section{References}

1. V. Belyukh, A. Danyluk, K. Glukhov, I. Stakhira, Phys. Solid State, 55(11), 2317 (2013).

2. I. M. Ashraf, H. A. Elshaikh, A. M. Badr, Indian J. Phys., 68, 467 (2007).

3. A. M. Badr, H. A. Elshaikh, I. M. Ashraf, J. Mod. Phys., 2, 12 (2011).

4. N. M. Megahid, Chinese J. Phys., 41, 130 (2003).

5. R. S. Mane, C. D. Lokhande, Mater. Chem. Phys., 65(1), 1 (2000).

6. V. Janickis, R. Stokienè, Chemija, 21(1), 17 (2010).

7. V. Janickis, R. Stokiene, N. Kreiveniene, Mater. Sci.-Medz., 17(4), 391 (2011).

8. Y. Ni, M. Shao, Z. Wu, F. Gao, X. Wei, Solid State Comun., 130(5), 297 (2004).

9. A. Mondal, P. Pramanik, Thin Solid Films, 110, 65 (1983).

10. V. Gopal, J. A. Harrington, Opt. Express, 11(24), 3182 (2003).

11. A. M. Badr, H. A. Elshaikh, I. M. Ashraf, Pramana J. Phys., 72(5), 871 (2009).

12. I. M. Ashraf, H. A. Elshaikh, A. M. Badr, Phys. Status Solidi $B, 241(4), 885$ (2004).

13. V. Estrella, R. Mejia, M. T. S. Nair, P. K. Nair, Mod. Phys. Lett. B, 15, 737 (2001).

14. I. M. Ashraf, H. A. Elshaikh, A. M. Badr, Cryst. Res. Technol., 39(1), 63 (2004).

15. H. A. Elshaikh, I. M. Ashraf, A. M. Badr, Egypt. J. Solids, 30, 199 (2007).

16. G. Giester, C. L. Lengauer, E. Tillmanns, J. Zemann, Solid State Chem., 168(1), 322 (2002).

17. S. Kashida, K. Nakamura, Solid State Chem., 110(2), 264 (1994).

18. V. Janickis, Polythionates, Monography, Technology, Kaunas (2006).

19. I. Ancutienè, V. Janickis, S. Grevys, A. Žebrauskas, Chemija, 4, 3 (1996).

20. R. M. Sardarly, A. P. Abdullaev, G. G. Guseinov, et al., Crystallogr. Rep., 45(4), 551 (2000).

21. A. Galdikas, A. Mironas, V. Strazdienè, et al., Sens. Actuators, B, 67, 76 (2000).

22. A. Šetkus, A. Galdikas, A. Mironas, et al., Thin Solid Films, 391, 275 (2001).

23. A. Šetkus, A. Galdikas, A. Mironas, et al., Sens. Actuators, B, 78, 208 (2001).

24. L. Ancutienè, V. Janickis, R. Ivanauskas, et al., Lithuanian Patent LT 4584 B, 1999. 
25. I. Ancutienè, V. Janickis, A. J. Galdikas, et al., Lithuanian Patent LT 4805 B, 2001.

26. V. Janickis, I. Ancutiene, R. Ivanauskas, et al., Colloid Polym. Sci., 281(1), 84 (2003).

27. I. Ancutiene, V. Janickis, R. Ivanauskas, Appl. Surf. Sci., 252(12), 4218 (2006).

28. V. Janickis, I. Ancutiene, J. Zukauskaite, Mater. Sci.-Medz., 13(2), 132 (2007).

29. I. Ancutiene, R. Ivanauskas, Proc. Est. Acad. Sci., 58(1), 35 (2009).

30. I. Acutiene, J. G. Navea, J. Baltrusaitis, Appl. Surf. Sci., 347, 520 (2015).

31. I. Ancutiene, V. Janickis, Prog. Colloid Polym. Sci., 116, 129 (2000).

32. I. Ancutiene, V. Janickis, Cent. Eur. J. Chem., 8(6), 1281 (2010).

33. I. Ancutiene, Mater. Sci.-Medz., 9(4), 141 (2000).

34. I. Ancutienè, V. Janickis, R. J. Giesa, Pol. J. Chem., 78, 349 (2004).

35. V. Janickis, R. Maciulevicius, R. Ivanauskas, et al., Colloid. Polym. Sci., 281(1), 84 (2003).

36. V. Estrella, M. T. S. Nair, P. K. Nair, Thin Solid Films, 414, 289 (2002).

37. A. S. Radtke, F. W. Dickson, Am. Mineral., 60, 559 (1975).

38. V. Estrella, M. T. S. Nair, P. K. Nair, Thin Solid Films, 414(2), 281 (2002).

39. C. D. Lokhande, Mater. Chem. Phys., 27(1), 1 (1991).

40. R. Ivanauskas, I. Prosyčevas, Mater. Sci.-Medz., 7(4), 272 (2001).

41. D. I. Ismailov, R. M. Sultanov, F. I. Aliyev, R. B. Shafizade, Thin Solid Films, 205(1), 1 (1991).

42. R. Ivanauskas, V. Janickis, I. Ancutienè, R. Stokienè, Cent. Eur. J. Chem., 7(4), 864 (2009).

43. I. Bruzaite, V. Janickis, I. Ancutiene, V. Snitka, Solid State Phenom., 106, 133 (2005).

44. I. Bruzaite, V. Snitka, V. Janickis, Phys. Status Solidi A, 203(9), 2274 (2006).

45. V. Janickis, I. Ancutienè, I. Bružaitè, Chem. Technol., 2(23), 35 (2002).

46. I. Bružaitè, I. Ancutienė, V. Janickis, R. Ivanauskas, Chem. Technol., 3(29), 44 (2003).

47. V. Janickis, I. Ancutienè, I. Bružaitè, V. Jasulaitienè, Mater. Sci.-Medz., 10(3), 231 (2004).

48. V. Janickis, I. Ancutiene, I. Bružaite, Chem. Technol., 1(35), 15 (2005).

49. I. Bruzaite, V. Snitka, V. Janickis, Pol. J. Chem., 81(12), 2049 (2007).

50. I. Bruzaite, V. Janickis, Mater. Sci--Medz., 14(2), 128 (2008).

51. J. Janickis, J. Valančiūnas, V. Zelionkaite,, V. Janickis, S. Grevys, Proc. Lith. Acad. Sci. Ser. B, 3(88), 83 (1975).

52. A. Babko, A. Pilipenko, Photometric Analysis. Method for Determination of Non-metals, Khimiya, Moscow (1974) [in Russian].
53. Analytical Methods for Atomic Absorption Spectrometry, Perkin Elmer Corporation (1973).

54. J. Tudo, B. C. R. Jolibois, Seances Acad. Sci., Ser. C, 280, 1375 (1975)

55. K. Nakamura, S. Kashiba, J. Phys. Soc. Jpn., 62, 3135 (1993).

56. D. Briggs, in: M. P. Seach (ed.), Practical Surface Analysis by Auger and X-ray Photoelectron Spectroscopy, John Wiley and Sons, Chichester (1983).

57. V. I. Nefedov, X-ray Photoelectron Spectroscopy of Chemical Compounds, Khimiya, Moscow (1984) [in Russian].

58. G. E. McGuire, G. K. Schweitzer, T. A. Carlson, Inorg. Chem., 12(10), 2450 (1973).

59. C. D. Wagner, W. M. Riggs, L. E. Davis, J. F. Moulder, Handbook of X-ray Photoelectron Spectroscopy, PerkinElmer Corporation, Minnesota (1978).

60. S. Grevys, V. Janickis, Proceedings of National Conference: Chemistry and Chemical Technology, Kaunas, Lithuania, 25 (1975) [in Lithuanian].

61. I. Bružaite, V. Janickis, Cent. Eur. J. Chem., 11(4), 629 (2013).

62. A. Žebrauskas, R. Lazauskienè, Chemistry, 4, 25 (1993) [in Russian].

\section{Vitalijus Janickis, Ingrida Bružaitė}

\section{AUKŠTOSIOS POLITIONATO RŪGŠTYS - PIRMTAKAI SUDARANT TALIO SULFIDŲ SLUOKSNIUS POLIETILENO PAVIRŠIUJE}

Santrauka

Patobulintas ir tyrinètas talio sulfidų plonų sluoksnių nusodinimo ant žemo tankio polietileno (LDPE), naudojant aukštųjų politionato rūgščių $\left(\mathrm{H}_{2} \mathrm{~S}_{n} \mathrm{O}_{6}, n=21,33,45\right)$ tirpalus, metodas. Sieros koncentracija LDPE plèvelèse dideja didinant rūgšties tirpalo temperatūrą, jos sieringumą ir išlaikymo tirpale trukmę. Kai sierintas polimeras veikiamas $\mathrm{Tl}(\mathrm{I})$ tirpalu, siera, esanti polimere, reaguoja su talio jonais, susidaro skirtingos sudeties talio sulfidų $\mathrm{Tl}_{\mathrm{x}} \mathrm{S}_{\mathrm{y}}$ sluoksniai. Rentgeno struktūrinè analizė LDPE patvirtino $\mathrm{Tl}_{\mathrm{x}} \mathrm{S}_{\mathrm{y}}$ sluoksnių susidarymą. Identifikuotos penkios talio sulfidų fazès: $\mathrm{TlS}, \mathrm{Tl}_{2} \mathrm{~S}, \mathrm{Tl}_{2} \mathrm{~S}_{2}, \mathrm{Tl}_{4} \mathrm{~S}_{3}$ ir $\mathrm{Tl}_{2} \mathrm{~S}_{5}$. TlS fazė dominuoja sluoksniuose. Cheminè ir fazinè $\mathrm{Tl}_{x} \mathrm{~S}_{y}$ sluoksnių sudetis taip pat identifikuota rentgeno fotoelektronine spektroskopija. Ji parodè, kad sudarytuose sluoksniuose yra TlS, $\mathrm{Tl}_{2} \mathrm{~S}_{2} \mathrm{Tl}_{2} \mathrm{SO}_{4}, \mathrm{Tl}(\mathrm{OH})_{3}, \mathrm{~S}_{8}$ ir $\mathrm{Tl}_{2} \mathrm{O}_{3}$ junginių. Talio sulfidų sluoksnių ir jų susidarymo mechanizmas nustatyti atominès jejgos mikroskopijos metodu: vyksta du procesai - sieros desorbcija ir talio druskos tirpalo sąveika su siera LDPE paviršiuje. Talio sulfidų sluoksniai nėra homogeniški, t. y. atskirų salelių pavidalo. Sudarant norimos cheminès ir fazinès sudèties talio sulfidų sluoksnius sorbciniu-difuziniu metodu nustatyti dèsningumai igalina tikslingai parinkti LDPE plèvelių sierinimo, naudojant aukštąsias politionato rūgštis, sąlygas. 
